\title{
Thyroid hormones are necessary for the metamorphosis of tarpon Megalops cyprinoides leptocephali
}

\author{
Jen-Chieh Shiao, Pung-Pung Hwang* \\ Institute of Cellular and Organismic Biology, Academia Sinica, 128, Section 2, Academia Road, Nankang, Taipei 11529, Taiwan
}

Received 23 October 2004; received in revised form 5 June 2005; accepted 15 October 2005

\begin{abstract}
This study investigates the effects of thyroxine $\left(\mathrm{T}_{4}\right)$, triiodothyronine $\left(\mathrm{T}_{3}\right)$ and thiourea $(\mathrm{TU})$ on the metamorphosis of tarpon Megalops cryprinoides leptocephali. TU is an anti-thyroid hormone drug that inhibits the production of $\mathrm{T}_{4}$ and $\mathrm{T}_{3}$ in the thyroid tissue. Fully grown tarpons leptocephali were collected at the river mouth and, in the laboratory, were immediately treated with 100 ppb $\mathrm{T}_{4}, 10 \mathrm{ppb} \mathrm{T}_{3}$, or $300 \mathrm{ppm}$ TU. The appropriate concentrations were validated in a preliminary dose response experiment. Morphological and physiological characteristics that indicate metamorphic processes were measured every 2 days. $\mathrm{T}_{4}$ and $\mathrm{T}_{3}$ slightly speeded up the metamorphosis of tarpons compared with the control group. The experimental treatments produced accelerated reductions in length, increases in head/body ratio, swimbladder development, and loss of body water and sodium. In contrast, TU treatment caused metamorphic stasis with complete inhibition of metamorphosis between days 6 and 8 . Thyroid hormone treatment stimulated fast otolith growth while TU treatment stopped otolith growth between days 6 and 9. Leptocephali in $\mathrm{T}_{4}, \mathrm{~T}_{3}$ and control groups completed metamorphosis in 10-14 days, but TU-treated tarpons remained in the metamorphic leptocephalus stage more than 22 days. In addition, the inhibition of leptocephalus metamorphosis by $300 \mathrm{ppm}$ TU can be reversed in the presence of $10 \mathrm{ppb} \mathrm{T}_{3}$. These results indicate that thyroid hormones are involved in regulating the metamorphosis of leptocephali.
\end{abstract}

(C) 2005 Elsevier B.V. All rights reserved.

Keywords: Leptocephalus; Metamorphosis; Tarpon; Thiourea; Thyroid hormone

\section{Introduction}

The tarpon (Elopiformes) and four other orders of teleosts, Albuliformes (bonefish), Anguilliformes (catadromous and marine eels), Notacanthiformes (spiny eels) and Saccopharyngiformes (gulper eels) have a distinctive larval stage called the leptocephalus. The willow-leaf shaped leptocephali greatly differ from

\footnotetext{
* Corresponding author. Tel.: +886 2 27899521; fax: +886 2 27899576.

E-mail address: pphwang@gate.sinica.edu.tw (P.-P. Hwang).
}

other teleostean larvae, both in physiology and morphology. The larval stages of leptocephali are highly variable among taxa and are usually longer than the larval stages of other teleosts. Larval durations range from approximately 1 month (e.g., Megalops cyprinoides; Tsukamoto and Okiyama, 1997; Tzeng et al., 1998) to more than half a year (e.g., Anguilla eels; Wang and Tzeng, 2000; Shiao et al., 2001, 2002). The extended larval duration is believed to be an evolutionary strategy for wide and distant larval dispersion (Scheltema and Williams, 1983). In addition, the metamorphosis of the leptocephalus to a juvenile is a critical 
period that influences whether the pelagic larvae can successfully transit to demersal habitats. However, the metamorphic process is rarely studied due to difficulties obtaining leptocephali.

Contrary to the swift development of other teleostean larvae, the cellular growth and metabolic rate of leptocephali are very slow and proceeds at a low level until metamorphosis commences (Bishop et al., 2000; Bishop and Torres, 2001). Energy is accumulated as lipid and proteoglycans as the size of the leptocephalus increases during the premetamorphic stage (Phase I, Pfeiler, 1999; Bishop and Torres, 1999). The acellular mass of lipid and proteoglycans are broken down to provide the nutrients required for metamorphosis (Phase II, Pfeiler, 1986). The leptocephali therefore do not need feeding during the metamorphosis.

Nutritional reserves enable leptocephali to display high plasticity in the timing of metamorphosis. Delayed metamorphosis of leptocephali has been reported in some Anguilla eels (Cheng and Tzeng, 1996; Shiao et al., 2001, 2002). Some coral reef fish larvae can delay metamorphosis somewhat until suitable demersal habitats are available (Victor, 1986; McCormick, 1999) but delayed metamorphosis is uncommon for most teleostean larvae (e.g., Searcy and Sponaugle, 2000). Thus, some fish are believed able to regulate the length of their larval stage by commencing or delaying metamorphosis.

The physiological mechanisms regulating the metamorphosis of leptocephali are poorly understood. Yamano et al. (1991) observed an abrupt increase of the thyroid hormones thyroxine $\left(\mathrm{T}_{4}\right)$ and triiodothyronine $\left(\mathrm{T}_{3}\right)$ in the conger eel (Conger myriaster) in early and late metamorphosis, respectively. This suggests that thyroid hormones may be involved in the metamorphosis of leptocephali. Exogenous thyroid hormones have been found to promote metamorphosis in some teleostean larvae e.g., flounder (Inui and Miwa, 1985; Miwa and Inui, 1987) and grouper (de Jesus et al., 1998). In contrast, treatment with thiourea (TU), which causes hypothyroidism, can retard metamorphosis of premetamorphic flounder (Miwa and Inui, 1987). Similar experiments have not been conducted on metamorphic leptocephali; thus, whether the metamorphosis of leptocephali is triggered and mediated by thyroid hormone is still unknown.

The Atlantic tarpon Megalops atlanticus supports important recreational fisheries in the Atlantic Ocean, Caribbean Sea and Gulf of Mexico (Cyr, 1991). However, the population of Atlantic tarpon appears to be declining in many areas. The significant decline of Atlantic tarpon has attracted the attention of fishery scientists and management, thus encouraging more studies on age and growth (Zerbi et al., 2001) and genetic structure (Blandon et al., 2003). This study will evaluate the relationship between the metamorphosis of leptocephali and thyroid hormones by using exogenous thyroid hormones and an anti-thyroid hormone drug. An increased knowledge of the basic biology of this poorly understood genus may contribute to management and conservation. Leptocephali undergo many physiological and morphological changes during metamorphosis, including an increase in metabolic rate, weight loss, size shrinkage, and profound change in body shape. In addition, otolith growth is widely regarded as a proxy of fish growth and a recorder of historic events. These physiological and morphological changes and otolith growth are the best monitors of the progression of metamorphosis among experimental treatments.

\section{Methods and materials}

\subsection{Fish collection}

Tarpon leptocephali were caught in the mouth of Gong-Shy-Tyan Brook, northern Taiwan. The salinity was approximately $20-30 \mathrm{ppt}$ at the sampling location. The leptocephali were collected in a funnel-shaped net as they drifted into the estuary with the rising tidal current. To avoid damage, the fragile leptocephali were carefully transferred to a container while still immersed in seawater. The leptocephali were brought to the laboratory and housed in glass aquariums.

\subsection{Treatment}

Leptocephalus tarpons were not fed. The tarpons collected on November 18 in 2002 received no treatment. The morphological and physiological changes of 3 to 7 leptocephali were monitored every other day during metamorphosis (see below).

A preliminary experiment was conducted to determine optimal concentrations of hormone and drug for testing. Tarpon leptocephali collected on June 17 in 2003 were used for this purpose. Batches of 35 leptocephali were reared in $10 \mathrm{~L}$ containers of $30 \mathrm{ppt}$ artificial seawater (SW) with various concentrations of $\mathrm{T}_{4}$ (10, 100 and $1000 \mathrm{ppb}), \mathrm{T}_{3}(1,10$ and $100 \mathrm{ppb})$, TU $(30,300$ and $3000 \mathrm{ppm})$ or no added hormones or drugs (control group). High concentrations of $\mathrm{T}_{4}(1000 \mathrm{ppm})$ and $\mathrm{T}_{3}(100 \mathrm{ppm})$ were dissolved in ethanol then diluted at various concentrations in seawater. Ethanol alone had no effect on tarpon growth in the control 

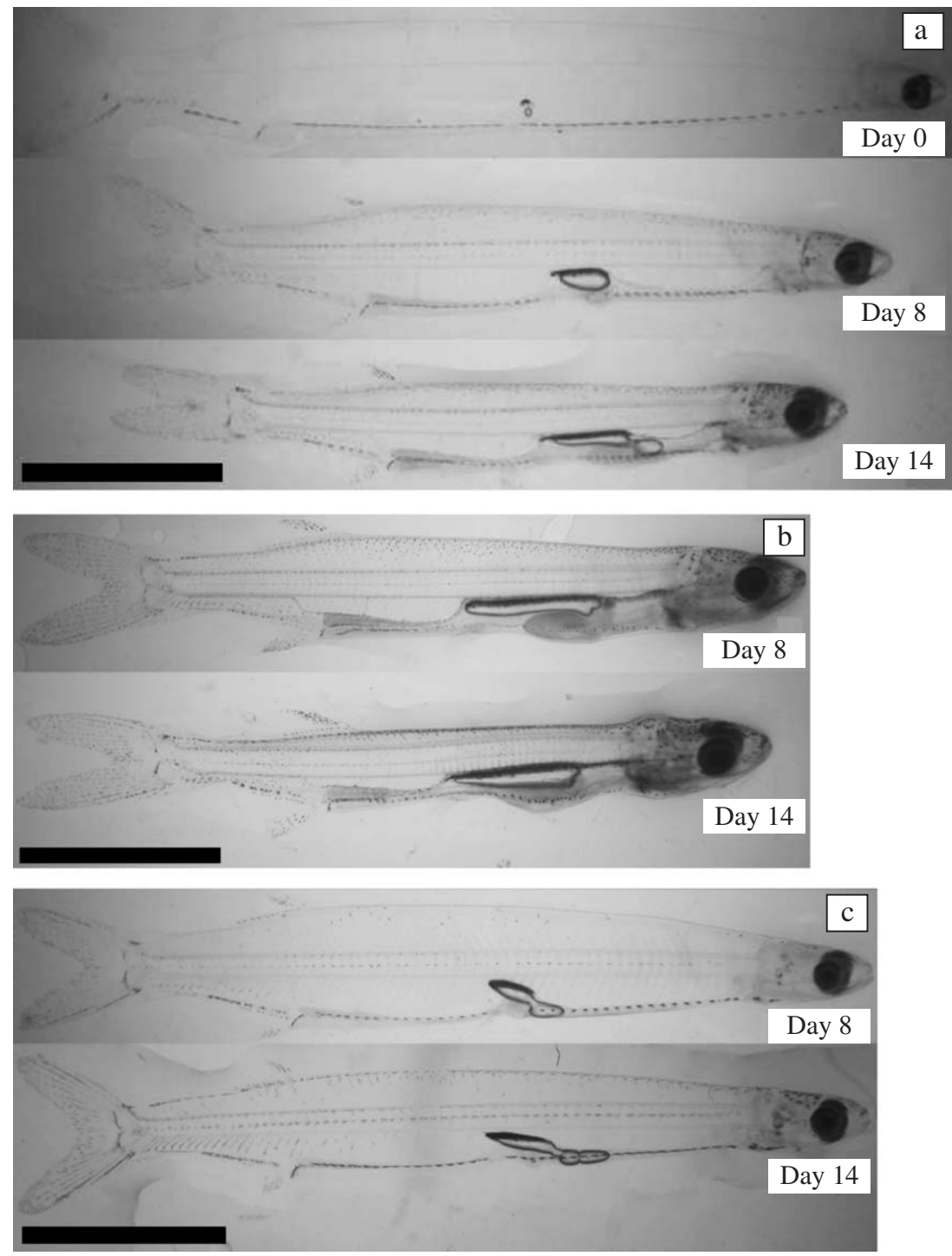

Fig. 1. Morphological changes of metamorphic tarpon M. cyprinoides among treatments. (a) Control, (b) $10 \mathrm{ppb} \mathrm{T}_{3}$, (c) $300 \mathrm{ppm} \mathrm{TU}$. Scale bar $=0.5 \mathrm{~cm}$.

group. These concentrations cover the range that was used in previous studies (Miwa and Inui, 1987; de Jesus et al., 1998). One-tenth of the water was exchanged with seawater containing the same concentration of $\mathrm{T}_{4}$, $\mathrm{T}_{3}$ or TU every 2 days. Water temperature was held at $25{ }^{\circ} \mathrm{C}$ and the photoperiod was set at 12 -h light/12-h darkness. The metamorphic tarpons were sacrificed at day 8 . Their morphologies were measured (see below) to determine the optimal concentrations affecting physical and morphological parameters.

In the main experiment, batches of approximately 200 leptocephali collected on July 14, 2003 were reared in $20 \mathrm{~L} \mathrm{SW}$ with concentrations of $100 \mathrm{ppb}$ $\mathrm{T}_{4}, 10 \mathrm{ppb} \mathrm{T}_{3}$ and $300 \mathrm{ppm}$ TU. Rearing conditions were similar to those of the preliminary experiment. Sixteen tarpons were randomly selected and removed from the aquaria every 2 days and their morphological characteristics were measured. Half of the 16 tarpons sampled every 2 day were used for sodium analysis. The tarpons surviving from each treatment at the end of the experiment were frozen at $-20{ }^{\circ} \mathrm{C}$ until otolith extraction.

The $T_{3}$ rescue experiment was conducted to evaluate if the blocking of metamorphosis by TU treatment can be resumed in the presence of thyroid hormone. Tarpon leptocephali collected on September 16 in 2004 were separated into 3 aquariums. One aquarium contained $300 \mathrm{ppm}$ TU. The second aquarium contained 

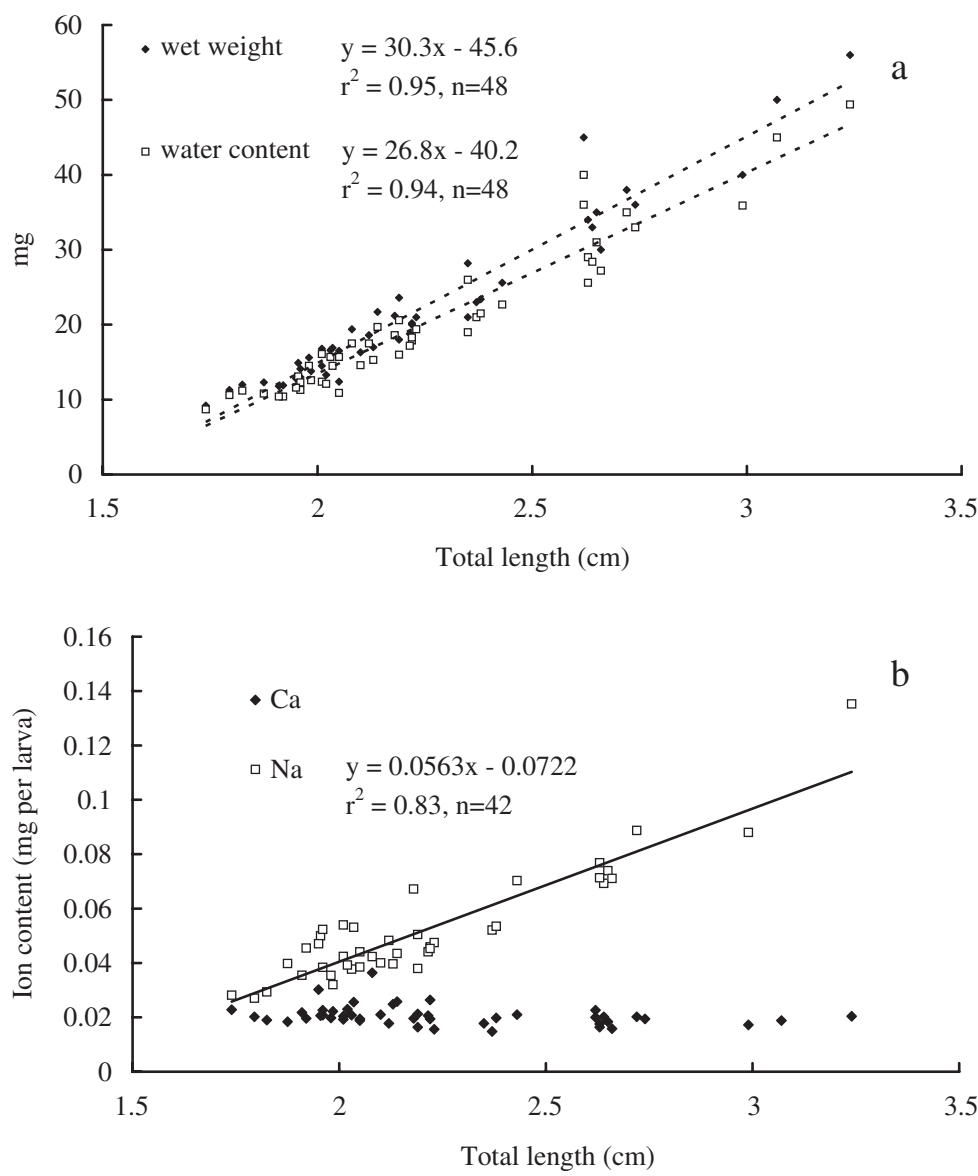

Fig. 2. The body shrinkage and ion content of leptocephalus tarpon $M$. cyprinoides during the metamorphosis.

$300 \mathrm{ppm} \mathrm{TU}$ and $10 \mathrm{ppb} \mathrm{T}_{3}$. There was no drug or thyroid hormone added to the third aquarium (control group). The total length and swimbladder length of 10 fish were measured at the day of capture to represent the initial value for all groups. Half of the water was exchanged every 2 days with the same concentration of drug or thyroid hormone. The development of approximately 10 fish from each treatment was compared every 3 days until day 12 in captivity. The tarpons surviving to the end of the experiment were frozen at $-20{ }^{\circ} \mathrm{C}$ until otolith extraction.

\subsection{Morphological and physiological measurement}

The metamorphic leptocephali were anaesthetized by MS 222 and photographed under a stereomicroscope equipped with a digital camera. Each tarpon was then washed with double-deionized water to avoid body surface contamination. The body surface was blotted dry with filter paper. The wet weight of each tarpon was measured to the nearest $0.1 \mathrm{mg}$. For sodium analysis, the tarpons were dried at $70{ }^{\circ} \mathrm{C}$ in an oven overnight and weighed (dry weight to 0.1 $\mathrm{mg}$ ). The water content of each tarpon was obtained by subtracting the dry weight from the wet weight of each fish. The dried tissues were dissolved overnight in $200 \mu \mathrm{l} 65 \% \mathrm{HNO}_{3}$ at $70{ }^{\circ} \mathrm{C}$ in the oven. Then the solution was diluted 250 -fold and analyzed by atomic absorption spectrophotometer (Hitachi Z5000). Total length, swimbladder length, head depth (through the middle of the eye, to $0.01 \mathrm{~mm}$ ) and maximum body depth (to $0.01 \mathrm{~mm}$ ) were measured on the images with the aid of a personal computer using the software Image-Pro plus, Media Cybernetics Inc. 1994.

\subsection{Otolith preparation}

Saggital otoliths were removed, dried in air and embedded with epofix resin. The otoliths were ground and polished to expose the core. Dilute $\mathrm{HCl}(0.05 \mathrm{M})$ was then used to etch the otolith for $20 \mathrm{~s}$. Etching 
Table 1

Head depth/maximum body depth $(\mathrm{H} / \mathrm{B})$ ratios of metamorphic tarpon after different treatments

\begin{tabular}{lllc}
\hline & H/B ratio & Sample sizes & Mortality (\%) \\
\hline $\begin{array}{l}\text { Control } \\
\text { Initial }\end{array}$ & $0.43 \pm 0.059$ & 20 & \\
$\quad$ Final & $0.56 \pm 0.057$ & 32 & 9 \\
$\mathrm{~T}_{3}$ & & & \\
$1 \mathrm{ppb}$ & $0.58 \pm 0.062$ & 29 & 17 \\
$10 \mathrm{ppb}$ & $0.64 \pm 0.059^{*}$ & 30 & 14 \\
$100 \mathrm{ppb}$ & $0.79 \pm 0.081^{*}$ & 32 & 9 \\
$\mathrm{~T}_{4}$ & & & \\
$10 \mathrm{ppb}$ & $0.63 \pm 0.073^{*}$ & 29 & 17 \\
$100 \mathrm{ppb}$ & $0.62 \pm 0.062 *$ & 32 & 9 \\
$1000 \mathrm{ppb}$ & $0.63 \pm 0.069 *$ & 28 & 20 \\
$\mathrm{TU}$ & & & 23 \\
$30 \mathrm{ppm}$ & $0.57 \pm 0.057$ & 27 & 100 \\
$300 \mathrm{ppm}$ & - & 0 & 9 \\
$3000 \mathrm{ppm}$ & $0.45 \pm 0.04 *$ & 32 & \\
\hline
\end{tabular}

The initial H/B ratio derives from the measurement of 20 tarpons at the day of catch. Other measurements are taken at day 8 . Values in the 300-ppm TU group are absent due to mortality at day 7 . The symbol "*" indicates a significant difference between the treatment and control group at day 8 ( $p<0.05$, Tukey's pairwise comparison). Sample sizes are the total survived tarpons.

aided the reading of otolith increments by enhancing the contrast of the daily growth increments under a compound light microscope. Images of the whole etched otolith were taken at $400 \times$ magnification under the light compound microscope equipped with a digital camera. The measurements were conducted from the maximum radius of each otolith using the software Image-Pro plus, Media Cybernetics Inc. 1994.

\subsection{Statistical analysis}

Data are expressed as means \pm S.D. ( $n=$ number of fish). Statistical differences among treatments were analyzed using one-way analysis of variance (ANOVA). Tukey's pairwise comparison was used to isolate groups that differed from the others if the data were normally distributed with equal variances. Otherwise, a Kruskal-Wallis one-way ANOVA test on ranks was used. Significance was set at $p<0.05$.

\section{Results}

\subsection{Body shrinkage during the metamorphosis}

For the control group, the fully grown leptocephalus tarpon had few ventral pigment spots, a primitive round swimbladder and a straight digestive tract at day 0 . At day 8 in captivity, the metamorphic tarpon showed a shrunken body, better-developed dorsal pigmentation, and a larger and more oval swimbladder. At day 14 , the leptocephalus tarpon became a whitebait larva, which had dense pigment spots, an elongated swimbladder and an advanced digestive tract (Fig. 1a). Compared with the control group, $\mathrm{T}_{3}$ treatment at $10 \mathrm{ppb}$ speeded up the development of pigmentation and the digestive tract and swimbladder (Fig. 1b). On the other hand, treatment with $300 \mathrm{ppm}$ TU caused growth stasis. The tarpons with TU treatment remained in an early metamorphic stage at days 8 to 14 . Little inflation of the swimbladder and few pigment spots were observed. The digestive tract remained straight without further development of the stomach and intestine coils (Fig. 1c).

The wet weight, water content and total length of the control-group tarpon leptocephali continuously decreased as metamorphosis proceeded. Significant linear relationships occurred between wet weight, water content and total length $\left(r^{2}=0.95\right.$ and 0.94 , respectively, $p<0.001$, Fig. 2a). The sodium content also decreased while the calcium content remained constant during metamorphosis. Sodium content was also significantly related to the total length $\left(r^{2}=0.83, p<0.001\right.$, Fig. $\left.2 b\right)$. These results indicated that total length, wet weight, water content and sodium content, but not calcium content, are good indicators of the metamorphic development of tarpon leptocephali.

\subsection{Preliminary experiment}

The head depth/maximum body depth $(\mathrm{H} / \mathrm{B})$ ratio of the control group increased from 0.43 at the day of catch to 0.56 at day 8 (Table 1). Metamorphic tarpon showed an evident dose response to $\mathrm{T}_{3}$ treatment and the $\mathrm{H} / \mathrm{B}$ ratios for the middle $(10 \mathrm{ppb})$ and highest $(100 \mathrm{ppb})$ doses were significantly larger than for the control group $(p<0.05)$. The $\mathrm{H} / \mathrm{B}$ ratios of metamorphic tarpon were approximately 0.63 in the 3 dose levels of the $\mathrm{T}_{4}$ treatment, which were all significantly higher than for the control group $(p<0.05)$. No dose response to the $T_{4}$ treatment was observed. All the fish suddenly died at the 7th day in the 300-ppm TU group for unknown reasons; thus their morphology was not measured. The lowest dose of TU (30 ppm) had no significant effect on the $\mathrm{H} / \mathrm{B}$ ratio of metamorphic tarpons. However, the highest dose of TU (3000 ppm) inhibited metamorphosis, yielding an $\mathrm{H} / \mathrm{B}$ ratio that was significantly smaller than for the control group $(p<0.05)$. Consequently, middle concentrations of $\mathrm{T}_{3}(10 \mathrm{ppb}), \mathrm{T}_{4}(100 \mathrm{ppb})$ and TU (300 
ppm) were used in the main experiment. Mortality ranged from $9 \%$ to $23 \%$, except for the $300-p p m$ TU group (Table 1).

\subsection{Main experiment}

\subsubsection{Wet weight}

The mean wet weight of the control, $\mathrm{T}_{3}$ and $\mathrm{T}_{4}$ groups decreased respectively from $37.8 \pm 6.0,34.1 \pm$ 6.4 and $34.0 \pm 5.5 \mathrm{mg}$ at day 2 to $17.1 \pm 4.0,17.1 \pm 2.5$ and $16.5 \pm 3.1 \mathrm{mg}$ at day 14 (Fig. 3a). An accelerated decrease occurred between day 2 and day 4 in the $T_{3}$ and $T_{4}$ groups and between day 4 and day 6 in the control group. For the TU treatment, the mean wet weight decreased from $30.6 \pm 6.0 \mathrm{mg}$ at day 2 to $23.1 \pm 4.7 \mathrm{mg}$ at day 10 , and increased slightly from day 10 to day $14(24.2 \pm 3.8 \mathrm{mg})$. Tarpons in the $\mathrm{T}_{3}$ and $\mathrm{T}_{4}$ groups were significantly lighter than in the control group only at day $4(p<0.05)$. However, mean wet weights of the TU group were significantly larger than for the control, $\mathrm{T}_{3}$ and $\mathrm{T}_{4}$ groups from day 4 to day 14 $(p<0.05)$. The changes in water content among treat- ments were very similar to the patterns of wet weight The mean water content of the TU group decreased more slowly than for the other groups and stopped decreasing after day 10 (data not shown).

\subsubsection{Total length}

The mean total length of the control group gradually decreased from $2.6 \pm 1.3 \mathrm{~cm}$ at day 2 to $1.9 \pm 0.1 \mathrm{~cm}$ at day 10 and maintained this length from days 10 to 14 (Fig. 3b). Mean total lengths of the $\mathrm{T}_{3}$ and $\mathrm{T}_{4}$ groups showed an accelerated decrease between day 2 $(2.6 \pm 0.1 \mathrm{~cm})$ and day $4(2.2 \pm 0.1 \mathrm{~cm})$ and gradually decreased from day 4 to day $14(1.8 \pm 0.1 \mathrm{~cm})$. The mean total length of the TU group showed a U-shaped growth pattern, decreasing slowly from day $2(2.5 \pm 0.1$ $\mathrm{cm})$ to day $10(2.1 \pm 0.1 \mathrm{~cm})$ and then increasing from day 10 to day $14(2.3 \pm 0.2 \mathrm{~cm})$. Mean total lengths of the $\mathrm{T}_{3}$ and $\mathrm{T}_{4}$ groups were significantly smaller than for the control group at days $4,6,12$ and $14(p<0.05)$. However, the mean total lengths of the TU group were significantly larger than for other groups after day 6 $(p<0.05)$
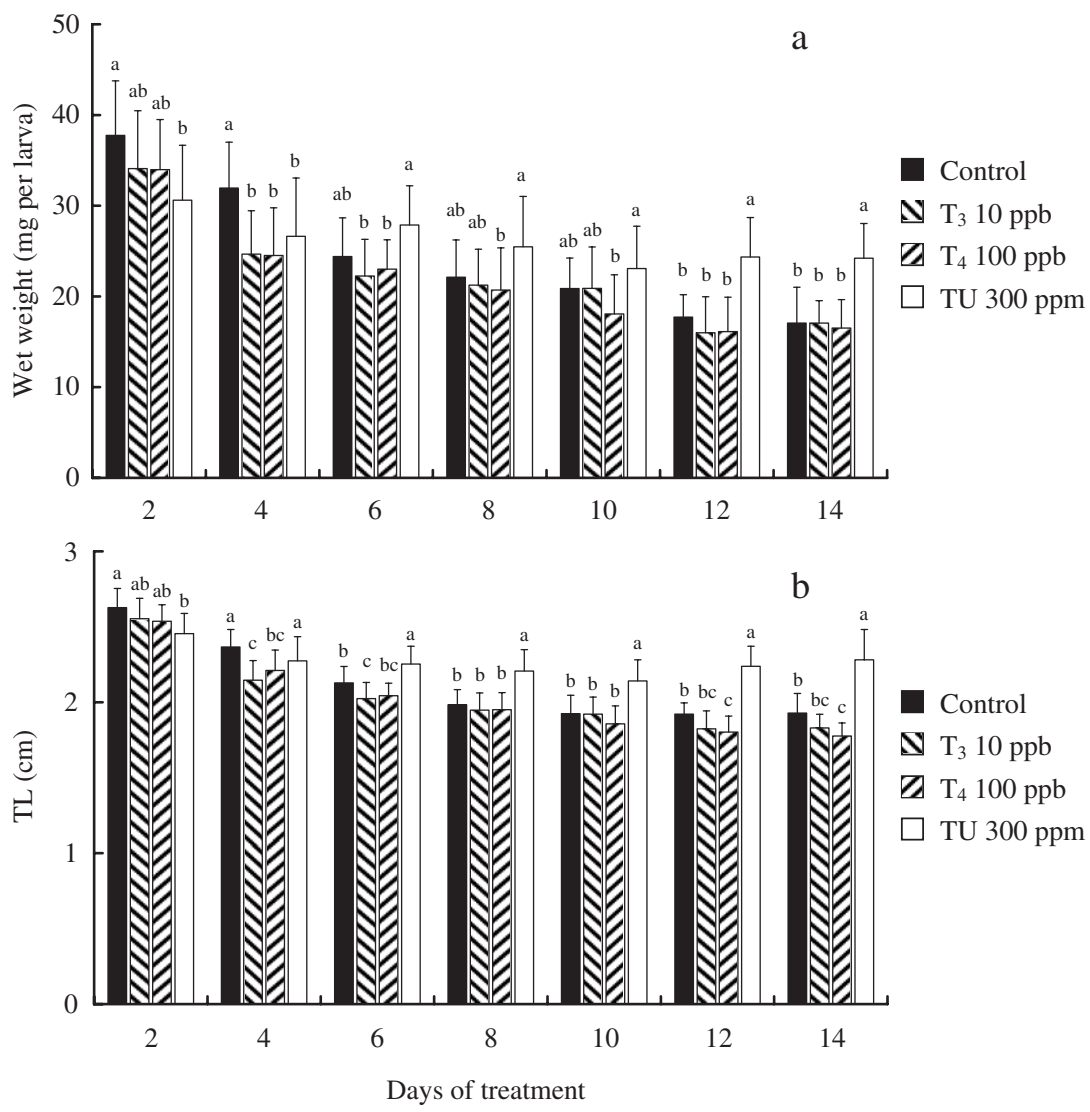

Fig. 3. Temporal changes among treatments in morphological and physiological characters of metamorphic tarpons $M$. cyprinoides. Error bar $=1$ S.D. Significant differences among treatments on the same day are represented by different letters $(p<0.05$, Tukey's pairwise comparison) 

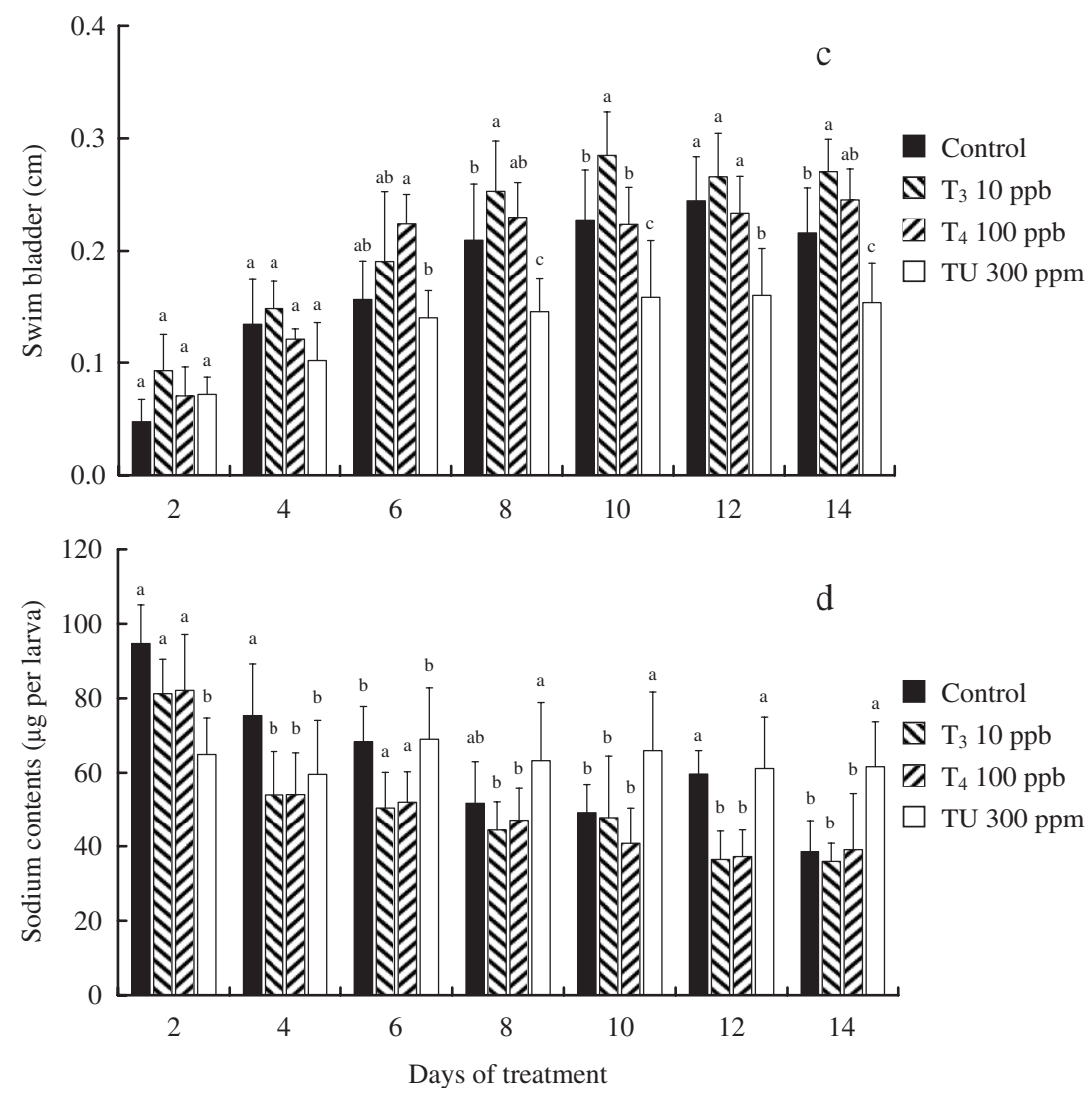

Fig. 3 (continued).

\subsubsection{Swimbladder}

The mean swimbladder length in the control, $\mathrm{T}_{3}$, and $\mathrm{T}_{4}$ groups increased, respectively, from $0.47 \pm$ $0.20,0.93 \pm 0.32$ and $0.70 \pm 0.26 \mathrm{~mm}$ at day 2 to $2.27 \pm 0.45,2.85 \pm 0.39$ and $2.24 \pm 0.33 \mathrm{~mm}$ at day 10 , and maintained this level between days 10 and
14 (Fig. 3c). The swimbladder of the $\mathrm{T}_{3}$ and $\mathrm{T}_{4}$ groups developed faster than for the control group. Significant differences between control and $\mathrm{T}_{3}$ groups were found at days 8,10 and $14(p<0.05)$. The TU group showed retarded swimbladder development. The swimbladder grew very slowly from $0.72 \pm 0.15 \mathrm{~mm}$ at day 2 to

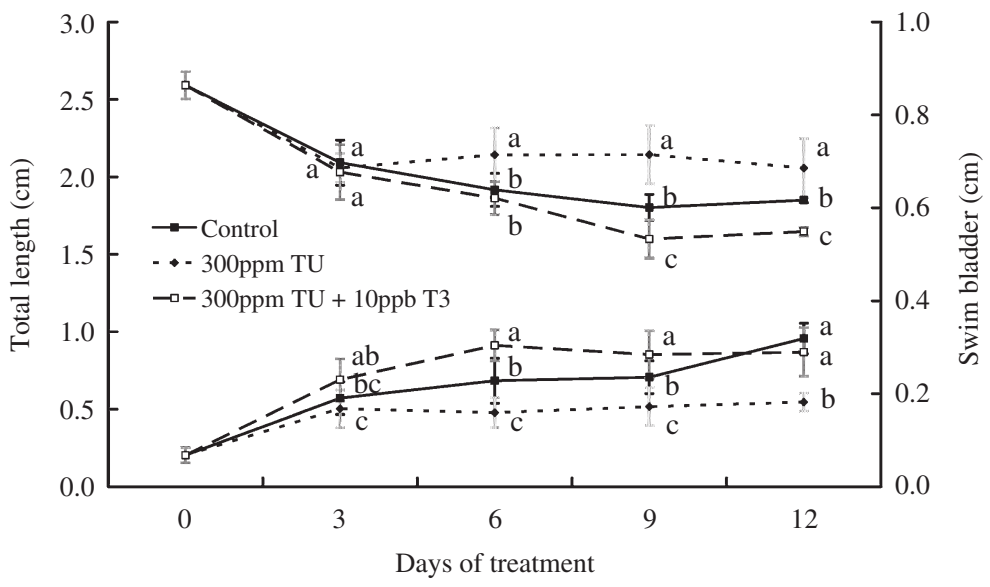

Fig. 4. Comparisons among treatments of total length and swimbladder length for metamorphic tarpon M. cyprinoides. Error bar=1 S.D. Significant differences among treatments on the same day are represented by different letters $(p<0.05$, Tukey's pairwise comparison). 
$1.40 \pm 0.24 \mathrm{~mm}$ at day 6 then stopped growing. Mean swimbladder lengths in the TU group were significantly smaller than for the other groups after day $8(p<0.05)$.

\subsubsection{Sodium content}

The mean sodium content of the control group decreased from $94.7 \pm 10.4 \mu \mathrm{g} /$ larva at day 2 to $38.5 \pm 8.5$ $\mu \mathrm{g} /$ larva at day 14 , with a slight increase between days 10 and 12 (Fig. 3d). The mean sodium content of the $T_{3}$ and $\mathrm{T}_{4}$ groups decreased from $81.3 \pm 9.2$ and $82.1 \pm 15$ $\mu \mathrm{g} /$ larva at day 2 to $35.9 \pm 4.9$ and $39.1 \pm 15.3 \mu \mathrm{g} /$ larva at day 14 , respectively, with a rapid decrease between days 2 and 4 . The mean sodium content per larva decreased more rapidly in the $T_{3}$ and $T_{4}$ groups than in the control group. Significant differences were found at days 4,6 and $12(p<0.05)$. The mean sodium content per larva of the TU group maintained a similar level from day $2(64.9 \pm 9.8 \mu \mathrm{g})$ to day $14(61.6 \pm$ $12 \mu \mathrm{g})$. The mean sodium content of the TU group was significantly smaller than for the other groups at day 2 but became significantly larger than for the other groups after day $6(p<0.05)$.

\subsection{T3 rescue experiment}

The mean total lengths of leptocephalus tarpons in the 300-ppm TU group decreased from $2.59 \pm 0.09 \mathrm{~cm}$ at day 0 to $2.06 \pm 0.09$ at day 3 , then maintained this level until the end of the experiment (Fig. 4). On the other hand, the mean total lengths decreased continuously from $2.59 \pm 0.09 \mathrm{~cm}$ at day 0 to $1.65 \pm 0.03 \mathrm{~cm}$ at day 12 in the group at $300 \mathrm{ppm}$ TU with $10 \mathrm{ppb} \mathrm{T}_{3}$. The mean total lengths for the group at $300 \mathrm{ppm}$ TU with 10 $\mathrm{ppb} \mathrm{T}_{3}$ was significantly smaller than the for the control and 300-ppm TU groups after day $3(p<0.05)$. In addition, the swimbladder grew faster in the group of $300 \mathrm{ppm}$ TU with $10 \mathrm{ppb} \mathrm{T}_{3}$ than in the group of 300 ppm TU from days 3 to $12(p<0.05)$. The swimbladders of the group at $300 \mathrm{ppm}$ TU with $10 \mathrm{ppb} \mathrm{T}_{3}$ were also significantly larger than that in the control group at days 6 and $9(p<0.05)$. These results indicated that TU cannot block the metamorphosis of leptocephali in the presence of thyroid hormone.

\subsubsection{Otolith growth}

Etching with $\mathrm{HCl}$ revealed the clear daily growth increments in the ground otoliths. A deeply etched check appeared around half of the otolith radius in all examined samples (Fig. 5). By tetracycline marking, Shiao and Huang (2004) found that the otolith check was deposited during the day of catch and they defined

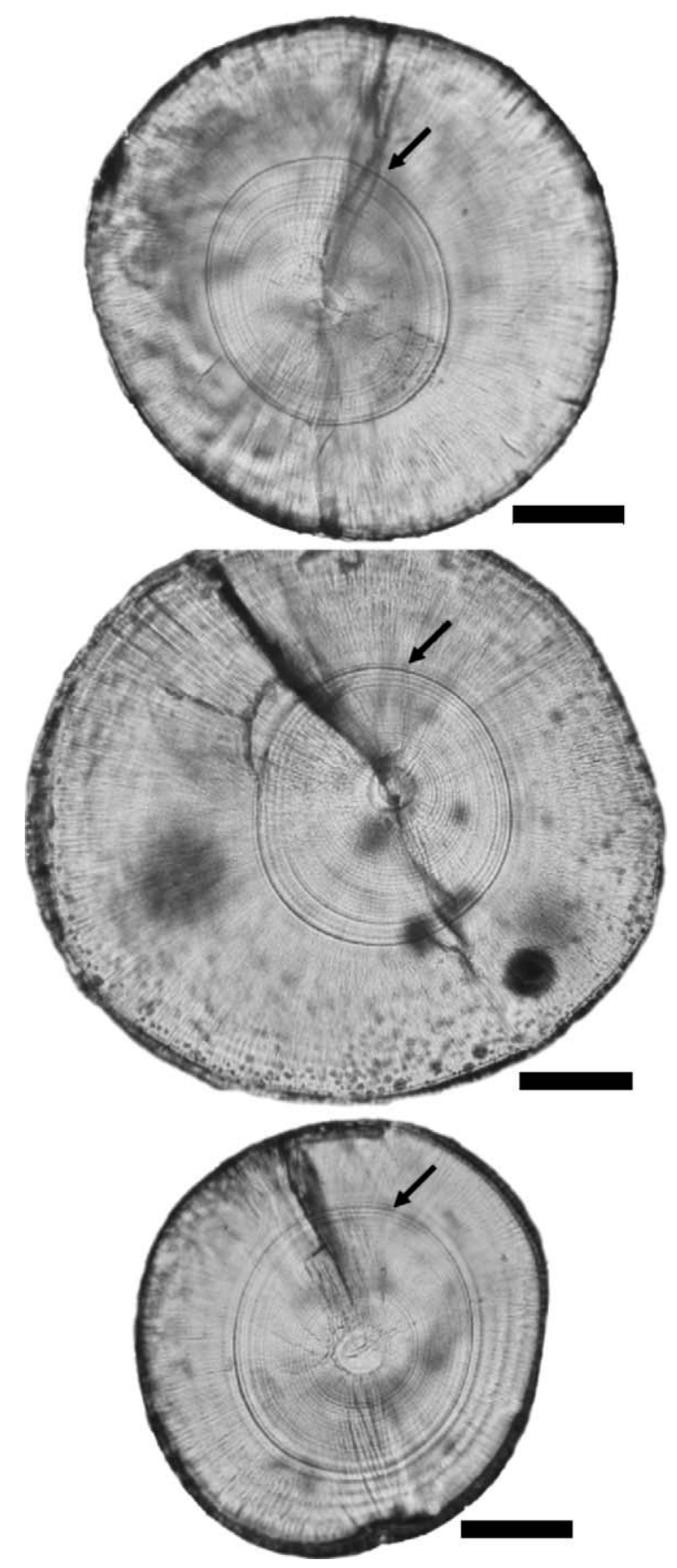

Fig. 5. M. cyprinoides. The daily growth increments of tarpon otoliths from different treatments. (a) Control, (b) $10 \mathrm{ppb} \mathrm{T}_{3}$, (c) $300 \mathrm{ppm} \mathrm{TU}$ Arrows indicate the captivity check. Bar $=50 \mu \mathrm{m}$.

this check as a captivity check. The mean ages of tarpon leptocephali collected in July 2003 were $27.9 \pm 3.6$ $(n=18), 29.2 \pm 2(n=13)$ and $28.1 \pm 3.2(n=15)$ days in the control, 10-ppb $\mathrm{T}_{3}$ and 300-ppm TU groups, respectively. There was no significant difference in ages among groups. The newly deposited increments 
totaled $13.2 \pm 0.4(n=17), 13 \pm 0(n=15)$ and $7.1 \pm 0.8$ $(n=15)$ rings in the control, $10 \mathrm{ppb} \mathrm{T}_{3}$ and $300 \mathrm{ppm} \mathrm{TU}$ groups, respectively. Otoliths of the $10 \mathrm{ppb} \mathrm{T}_{3}$-treated group and control fish grew throughout the experimental period, but otoliths of the $300 \mathrm{ppm}$ TU group did not grow between day 6 and day 9 . The distances from the captivity check to otolith edge were $77.0 \pm 12.0(n=17)$, $91.9 \pm 7.2(n=14)$ and $47.9 \pm 6.3(n=16) \mu \mathrm{m}$ in the control, $\mathrm{T}_{3}$ and TU groups, respectively. The lengths of newly grown otoliths of the $10 \mathrm{ppb} \mathrm{T}_{3}$ group were significantly larger than for the control and $300 \mathrm{ppm}$ TU groups, and the control group was also significantly larger than the $300 \mathrm{ppm}$ TU group $(p<0.05)$.

For the $\mathrm{T}_{3}$ rescue experiments, the mean ages of tarpon leptocephali collected in September 2004 were $28.3 \pm 2.7(n=16)$ days for the control group, $29.7 \pm 3.1$ $(n=15)$ days for the $300 \mathrm{ppm}$ TU with $10 \mathrm{ppb} \mathrm{T}_{3}$ group and $28.7 \pm 2.8(n=18)$ days for the $300 \mathrm{ppm}$ TU group. There was no significant difference in the larval ages among groups. When the tarpons were exposed simultaneously to $300 \mathrm{ppm} \mathrm{TU}$ and $10 \mathrm{ppb} \mathrm{T}_{3}$, the otolith growth increment was still deposited in the daily period. In addition, new otolith growth of the tarpons exposed to $300 \mathrm{ppm}$ TU with $10 \mathrm{ppb} \mathrm{T}_{3}(10.8 \pm 0.6$ rings, $73.4 \pm 8.8 \mu \mathrm{m}, n=15)$ was similar to that of the control group $(10.7 \pm 0.6$ rings, $61.1 \pm 12.2 \mu \mathrm{m}, n=16)$ but significantly greater than for that in $300 \mathrm{ppm}$ TU $(5.9 \pm 1.5$ rings, $34.0 \pm 11.2 \mu \mathrm{m}, n=18, p<0.001)$ (Fig. 6). These results indicate that $\mathrm{T}_{3}$ can rescue the inhibitory effects on otolith growth by TU treatment during the leptocephalus metamorphosis.

\section{Discussion}

\subsection{Optimal concentration of thyroid hormones and thiourea}

Thyroid hormones have been used to promote metamorphosis in some teleostean larvae. High doses of thyroid hormones increased mortality or the rate of abnormalities in the larvae of brown trout (Mylonas et al., 1994), striped bass (Huang et al., 1996) and grouper (de Jesus et al., 1998). Since there were no previous studies of thyroid hormones on tarpon metamorphosis, the evaluation of suitable doses was necessary. In the preliminary experiment, the effects of 3 concentrations of $T_{3}(1,10$ and $100 \mathrm{ppb}), \mathrm{T}_{4}(10,100$ and $1000 \mathrm{ppb})$ and $\mathrm{TU}(30,300$ and $3000 \mathrm{ppm})$ on metamorphic leptocephali were evaluated. No unexpected deaths or abnormalities were observed in these treatments, except the sudden death of the group of 300 ppm TU at day 7. The concentration of $300 \mathrm{ppm}$ TU was unlikely to be the cause of death since a concentration 10 times higher (3000 ppm) did not cause evident deaths, nor did the $300 \mathrm{ppm}$ TU in the main experiment. During the trial, the water was only moderately aerated and poor water quality or pollution from an unknown source may have caused the mortalities in the 300-ppm TU group.

One ppb $\mathrm{T}_{3}$ and $30 \mathrm{ppm}$ TU did not significantly promote or inhibit the metamorphosis. Miwa and Inui (1987) also found that $1 \mathrm{ppb} \mathrm{T}_{3}$ had no significant effect on the metamorphosis of flounder, but $30 \mathrm{ppm}$ TU had

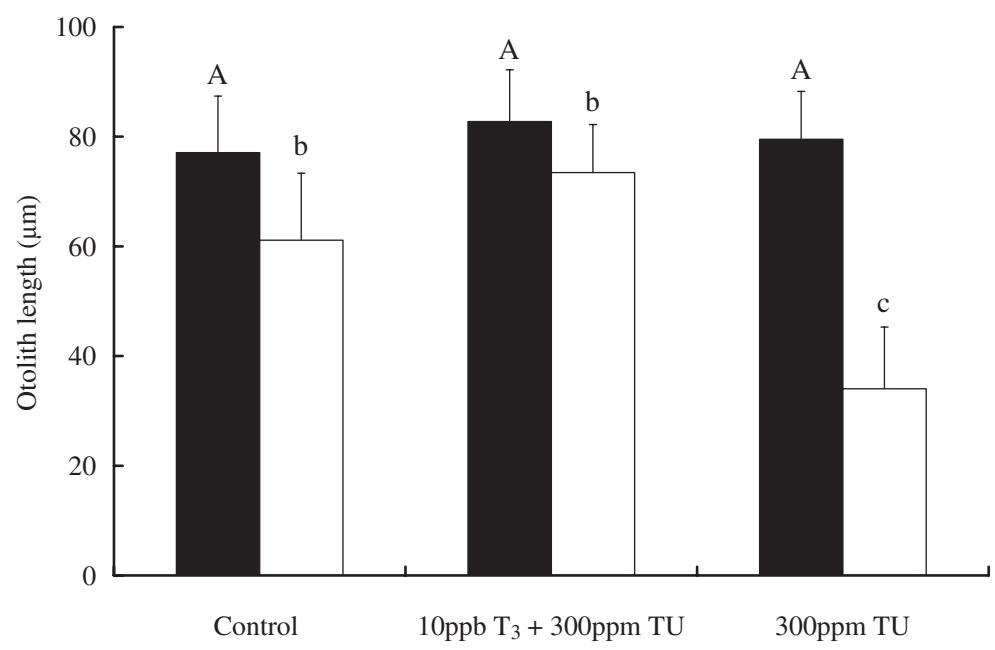

Fig. 6. M. cyprinoides. Before different treatments, the otolith lengths at the leptocephalus stage (from the primordium to captivity check, closed histogram) are consistent. After different treatments for 12 days, significant differences in mean otolith lengths occur during the metamorphic stage (from captivity check to otolith edge, open histogram). Error bar=1 S.D. Different letters indicate the significant difference among groups (KruskalWallis one-way ANOVA test on ranks, $p<0.05$ ) in each stage. 
an inhibitory effect. Miwa et al. (1988) treated the premetamorphic flounder with TU before the thyroxine surge occurred, so that inhibition of metamorphosis was achieved by the low dose of $30 \mathrm{ppm}$ TU. Thyroid tissues of fully grown leptocephali might be well-developed and mass secretion of thyroid hormones already started. Therefore, a higher dose of TU (300 ppm) would be needed to inhibit metamorphosis in our trials. Treatments with 10,100 and $1000 \mathrm{ppb}_{4}$ had a similar effect on the metamorphosis of tarpons. Thyroid glands secrete predominately $T_{4}$ rather than $T_{3}$. However $T_{4}$ converts to its biologically active form, $\mathrm{T}_{3}$, and stimulates growth because thyroid hormone receptors have a much higher affinity to $T_{3}$ than to $T_{4}$ (Eales, 1985). The observation of no evident dose response may reflect the active regulation by leptocephali of the catalysis of $\mathrm{T}_{4}$ to $\mathrm{T}_{3}$ or the incomplete solubility of high concentrations (e.g. 100 and $1000 \mathrm{ppb}$ ) of $\mathrm{T}_{4}$ in seawater.

\subsection{Effects of thyroid hormones and thiourea on metamorphic tarpons}

Exogenous thyroid hormones slightly accelerated the decrease of total length, wet weight, water content and sodium content of tarpons in early metamorphosis (days 2-4), and promoted faster growth of the swimbladder (Fig. 3). It is unexpected that thyroid hormones treatment did not prominently speed up the process of metamorphosis compared with the control group. The captured tarpons were fully grown leptocephali (Tsukamoto and Okiyama, 1997) and had immediately or already commenced metamorphosis in captivity. This indicated that the captured leptocephali were already secreting thyroid hormones that may have occupied most thyroid hormone receptors. Therefore, the exogenous thyroid hormones could only cause an additive effect, rather than a significant promotion of metamorphosis. Another reason is that only $1 / 10$ of the water and drugs were exchanged every 2 days in the experiments of 2003. This may cause lower concentrations of the drug and thyroid hormone than was expected. When half of the water was exchanged every 2 days in the experiments of 2004, the thyroid hormone significantly speeded up the metamorphosis relative to the control group (Fig. 4). At the end of the main experiment, control and thyroid hormone-treated groups had similar morphological and physiological characters. After metamorphosis, tarpons enter a sluggish growth phase, as so-called "whitebait" larvae. This stage lasts several weeks without evident growth (Tsukamoto and Okiyama, 1993, 1997). Therefore, the minor differences in early metamorphosis between the thyroid hormone-treated and control groups vanish in the whitebait stage. However, tarpons treated with thyroid hormones have faster otolith growth than does the control group. This indicated that thyroid hormones indeed speeded up the growth and metamorphic process of the tarpons. On the other hand, TU can retard or completely inhibit metamorphosis. The retarded growth caused by TU was extensive, covering almost all tissues in metamorphic tarpons. Inui et al. (1995) suggested that the changes in tissues of metamorphic flounder resulted from tissue-specific programming of gene expression, which is controlled by thyroid hormones. Development of each tissue stimulated by thyroid hormones is controlled at the receptor level by the differential expression of thyroid hormone receptors (Yamano and Miwa, 1998). Therefore, thyroid hormone receptors might exist, as in flounder, in almost all tissues of metamorphic tarpons since thyroid action in early tissue development seems universal among fish, amphibians and mammals (Inui et al., 1995; Shi et al., 1996; Koibuchi and Chin, 2000).

Otolith daily growth increment width was relatively narrow during the leptocephalus stage and fluctuated between 1 and $3 \mu \mathrm{m}$ in all examined otoliths. At the commencement of metamorphosis, the increment width abruptly increased from approximately $2 \mu \mathrm{m}$ to $7-13$ $\mu \mathrm{m}(9.6 \pm 2.1 \mu \mathrm{m}, n=17)$ in the control group (Fig. 5). This dramatic increase of daily growth increment can be stopped by $300 \mathrm{ppm}$ TU. These results indicated that thyroid hormones are involved in the metamorphosis of leptocephalus tarpons. Patterns of daily otolith growth were consistent with other morphological changes in tarpons. For example, total length, wet weight, water and sodium content stopped decreasing and swimbladder growth ceased at day 6 to day 8 after treatment with 300 ppm TU while otolith grow stopped beginning from day 6 to day 9. Thyroid hormones have a halflife of 6 days (Toft, 1994). The thyroid hormones that existed before TU treatment can serve as a reservoir that stimulates metamorphosis progress for several days until they are exhausted. In this study, TU-treated metamorphic tarpons remained in a metamorphic leptocephalus stage for at least 22 days without feeding. The leptocephali displayed an astonishing vitality and a highly plastic metamorphic process.

\subsection{Thyroid hormones and growth strategy of leptocephali}

Leptocephali gradually acquire metamorphic competence during the late leptocephalus stage when a minimal size, age and accumulated nutrient supply are reached. 
Leptocephalus tarpon metamorphose from 21 to 35 days after hatching (Shiao and Hwang, 2004). Larval duration of Anguilla leptocephali can vary up to more than 100 days (130 to 245 days, Shiao et al., 2001, 2002) within the species. Fish with a longer pre-competent larval stage usually have a longer metamorphic-competent stage (Jackson and Strathmann, 1981). A long metamorphiccompetent stage assures larvae of a successful settlement at a suitable habitat. This plasticity of larval stage duration may arise from growth differences among individuals as well as the ability to delay metamorphosis. For example, Tanaka (2003) recently reported the first successful rearing of Anguilla japonica leptocephali to glass eels. The premetamorphic stage (250 days) was approximately double the length of that of wild larvae due to an incomplete diet. In addition, prevailing theory believes Anguilla leptocephali can metamorphose into glass eels only when they sense the continental shelf. The ability to delay metamorphosis in the absence of a suitable habitat has been reported in other species (Victor, 1986; McCormick, 1999). This hypothesis indicates that metamorphic-competent leptocephali are able to determine when to commence metamorphosis. This study demonstrates the necessity of thyroid hormones for the metamorphosis of leptocephalus tarpons. Therefore, a possible reaction from environmental stimulation to physiological response is proposed herein: metamorphic-competent leptocephali sense a suitable habitat and start physiological responses through the hypothalamic-hypophyseal-thyroidal axis. The hypothalamus produces thyrotropin-releasing hormone and stimulates the secretion of thyroidstimulating hormone by the pituitary, which in turn stimulates the secretion of thyroxine $\left(\mathrm{T}_{4}\right)$. A thyroid hormone surge then triggers the leptocephalus metamorphosis. Alternatively, the leptocephali can delay metamorphosis for a long time, as demonstrated in this study, by regulating thyroid hormones secretion if no suitable habitat is available. This investigation of the effects of thyroid hormones and the anti-thyroid hormone drug, thiourea, on the metamorphosis of tarpon leptocephali suggests that the metamorphosis of leptocephali is mediated by thyroid hormones.

\section{Acknowledgements}

This study was conducted with financial support from the National Science Council of Republic of China (Contract No. NSC92-2811-B-001-068). We thank C.H. Shen and H.H. Ho for research assistance and suggestions on the manuscript from B. Jessop, D. Cairns and H. Lamson. [SS]

\section{References}

Bishop, R.E., Torres, J.J., 1999. Leptocephalus energetics: metabolism and excretion. J. Exp. Biol. 202, 2485-2493.

Bishop, R.E., Torres, J.J., 2001. Leptocephalus energetics: assembly of the energetics equation. Mar. Biol. 138, 1093-1098.

Bishop, R.E., Torres, J.J., Crabtree, R.E., 2000. Chemical composition and growth indices in leptocephalus larvae. Mar. Biol. 137, $205-214$.

Blandon, I.R., Garcia de Leon, F.J., Ward, R., Van Den Bussche, R.A., Needleman, D.S., 2003. Studies in conservation genetics of tarpon (Megalops atlanticus): V. Isolation and characterization of microsatellite loci. Mol. Ecol. Notes 3, 632-634.

Cheng, P.W., Tzeng, W.N., 1996. Timing of metamorphosis and estuarine arrival across the dispersal range of the Japanese eel Anguilla japonica. Mar. Ecol. Prog. Ser. 131, 87-96.

Cyr, E.C., 1991. Aspects of the life history of the tarpon Megalops atlanticus from South Florida. Ph.D. Dissertation. University of South Carolina, Columbia. 138 pp.

de Jesus, E.G., Toledo, J.D., Simpas, M.S., 1998. Thyroid hormones promote early metamorphosis in grouper (Epinephelus coioides) larvae. Gen. Comp. Endocrinol. 112, 10-16.

Eales, J.G., 1985. The peripheral metabolism of thyroid hormones and regulation of thyroidal status in poikilotherms. Can. J. Zool. 63, $1217-1231$.

Huang, L., Specker, J.L., Bengtson, D.A., 1996. Effect of triiodothyronine on the growth and survival of striped bass (Morone saxatilis). Fish Physiol. Biochem. 15, 57-64.

Inui, Y., Miwa, S., 1985. Thyroid hormone induces metamorphosis of flounder larvae. Gen. Comp. Endocrinol. 60, 450-454.

Inui, Y., Yamano, K., Miwa, S., 1995. The role of thyroid hormone in tissue development in metamorphosing flounder. Aquaculture 135, 87-98.

Jackson, G.A., Strathmann, R.R., 1981. Larval mortality from offshore mixing as a link between precompetent and competent periods of development. Am. Nat. 118, 16-26.

Koibuchi, N., Chin, W.W., 2000. Thyroid hormone action and brain development. Trends Endocrinol. Metab. 11, 123-128.

McCormick, M.I., 1999. Delayed metamorphosis of a tropical reef fish (Acanthurus triostegus): a field experiment. Mar. Ecol. Prog. Ser. 176, 25-38.

Miwa, S., Inui, Y., 1987. Effects of various doses of thyroxine and Triiodothyronine on the metamorphosis of flounder. Gen. Comp. Endocrinol. 67, 356-363.

Miwa, S., Tagawa, M., Inui, Y., Hirano, T., 1988. Thyroxine surge in metamorphosing flounder larvae. Gen. Comp. Endocrinol. 70, $158-163$.

Mylonas, C.C., Sullivan, C.V., Hinshaw, J.M., 1994. Thyroid hormones in brown trout (Salmo trutta) reproduction and early development. Fish Physiol. Biochem. 13, 485-493.

Pfeiler, E., 1986. Towards an explanation of the developmental strategy in leptocephalus lavae of marine teleost fishes. Environ. Biol. Fisches 15, 3-13.

Pfeiler, E., 1999. Developmental physiology of elopomorph leptocephali. Comp. Biochem. Physiol., A 123, 113-128.

Scheltema, R.S., Williams, I.P., 1983. Long-distance dispersal of planktonic larvae and the biogeography and evolution of some Polynesian and Western Pacific mollusks. Bull. Mar. Sci. 33, 545-565.

Searcy, S.P., Sponaugle, S., 2000. Variable larval growth in a coral reef fish. Mar. Ecol. Prog. Ser. 206, 213-226. 
Shi, Y.B., Wong, J., Puzianowska-Kuznicka, M., Stolow, M.A., 1996. Tadpole competence and tissue-specific temporal regulation of amphibian metamorphosis: role of thyroid hormone and its receptors. BioEssays 18, 391-399.

Shiao, J.C., Hwang, P.P., 2004. Thyroid hormones are necessary for teleostean otolith growth. Mar. Ecol. Prog. Ser. 278, 271-278.

Shiao, J.C., Tzeng, W.N., Collins, A., Jellyman, D.J., 2001. Dispersal pattern of glass eel stage of Anguilla australis revealed by otolith growth increments. Mar. Ecol. Prog. Ser. 219, 241-250.

Shiao, J.C., Tzeng, W.N., Collins, A., Iizuka, Y., 2002. Role of marine larval duration and growth rate of glass eels in determining the distribution of Anguilla reinhardtii and A. australis on Australian eastern coasts. Mar. Freshw. Res. 53, 687-695.

Tanaka, H., 2003. Techniques for larval rearing. In: Aida, K., Tsukamoto, K., Yamauchi, K. (Eds.), Eel Biology. Springer-Verlag, Tokyo, pp. 427-434.

Toft, A.D., 1994. Thyroxine therapy. N. Engl. J. Med. 331, 174-180.

Tsukamoto, Y., Okiyama, M., 1993. Growth during the early life history of the Pacific tarpon, Megalops cyprinoides. Jpn. J. Ichthyol. 39, 379-386 (in Japanese with English summary).

Tsukamoto, Y., Okiyama, M., 1997. Metamorphosis of the Pacific tarpon, Megalops cyprinoides (Elopiformes, Megalopidae) with remarks on development patterns in the Elopomorpha. Bull. Mar. Sci. 60 (1), 23-36.

Tzeng, W.N., Wu, C.E., Wang, Y.T., 1998. Age of Pacific tarpon, Megalops cyprinoides, at estuarine arrival and growth during metamorphosis. Zool. Stud. 37 (3), 177-183.

Victor, B.C., 1986. Delayed metamorphosis with reduced larval growth in a coral reef fish (Thalassoma bifasciatum). Can. J. Fish. Aquat. Sci. 43, 1208-1213.

Wang, C.H., Tzeng, W.N., 2000. The timing of metamorphosis and growth rates of American and European eel leptocephali: a mechanism of larval segregative migration. Fish. Res. 46, 191-205.

Yamano, K., Miwa, S., 1998. Differential gene expression of thyroid hormone receptor $\alpha$ and $\beta$ in Fish Development. Gen. Comp. Endocrinol. 109, 75-85.

Yamano, K., Tagawa, M., de Jesus, E.G., Hirano, T., Miwa, S., Inui, Y., 1991. Changes in whole body concentrations of thyroid hormones and cortisol in metamorphosing conger eel. J. Comp. Physiol., B 161, 371-375.

Zerbi, A., Aliaume, C., Joyeux, J.C., 2001. Growth of juvenile tarpon in Puerto Rican Estuaries. ICES J. Mar. Sci. 58, 87-95. 